\title{
Cigarette smoking and dental implant tooth replacement therapy: A questionnaire survey among patients receiving implant prosthetic treatment
}

\author{
Beata Kubic-Filiks ${ }^{1}$, Agnieszka Koszuta ${ }^{2}$, Jolanta Szymanska ${ }^{1 \star}$ \\ ${ }^{1}$ Chair and Department of Paedodontics, Medical University of Lublin, 7 Karmelicka, 20-081 Lublin, Poland \\ ${ }^{2}$ Non-Public Health Care Centre "Dental", Tomaszow Mazowiecki, Poland
}

\section{ARTICLE INFO \\ Received 01 December 2014 Accepted 17 December 2014}

\section{Keywords:}

nicotinism,

implant prosthetic, pain.

\begin{abstract}
Chronic nicotinism has negative effects, both local and systemic. Its local effects are related to both the immediate thermal influence, as well as the toxic action of the substances contained in the smoke. In addition, the microflora colonizing dental plague is changed. The damage and the inflammatory processes that are incurred, affect the bone tissue of the alveolar processes, the mucosa, gums, and the tooth enamel. In this study, the tobacco smoking-related profile of patients being treated by way of implants was determined. Moreover, the relationship between cigarette smoking and pain sensation was assessed in patients undergoing surgical and prosthetic procedures in the oral cavity. The questionnaire survey covered 464 patients receiving prosthetic treatment at the "Dental" Non-Public Health Care Centre in Tomaszow Mazowiecki. The patients answered questions concerning their sex, age, the period of smoking, number of cigarettes smoked per day and the sensation of pain during bone reconstruction, implant placement and prosthetic procedures. The most numerous group of patients treated with implants were women: either non-smoking or smoking for less than 20 years at a level of less than 20 cigarettes a day, and men aged 40-60 years who have been smoking for over 20 years, at more than 20 cigarettes a day. The results of the survey reveal that non-smoking patients felt pain during bone reconstruction, implant placement and prosthetic procedures more frequently.
\end{abstract}

\section{INTRODUCTION}

Nicotinism is the term utilised to describe the effect of chronic, years-long exposure upon individuals, to the nicotine contained in tobacco. It may be induced by either active and passive inhalation of tobacco combustion products (cigarette, cigar or pipe smoke), by consuming tobacco essence (chewing tobacco leaves) or through drawing snuff through the nose [7].

Tobacco smoke is a very unstable aerosol whose chemical properties change in a short time. It consists of a gas phase (i.e. volatile substances), and a particle phase (composed of tarry substances) $[3,7]$. The gas phase contains carbon monoxide, hydrogen cyanide (a toxic compound that blocks the activity of respiratory enzymes), nitrogen oxides and other gasses. The particle phase is comprised of polycyclic aromatic hydrocarbons (e.g. benzopyrene, indane, fluorine,

\section{Corresponding author}

e-mail: : szymanska.lublin@gmail.com and other chemicals - all showing carcinogenic properties), heavy metals (e.g. thallium, arsenic, polonium, lead, cobalt, cadmium, nickel, mercury, and other elements), phenols, aldehydes, ketones, and many other chemicals $[3,4,7]$.

Chronic nicotinism has negative effects that are both local and systemic. The local effects are related to the immediate thermal influence (the temperature of smouldering tobacco leaves can exceed $900^{\circ} \mathrm{C}$, while the temperature in the oral cavity can reach $+60^{\circ} \mathrm{C}$ ) and the toxic action of the substances contained in the smoke. The systemic effect of tobacco smoke is manifested through a set of disorders induced at every level of the organism's immune response [5]. Furthermore, the saliva undergoes certain changes as a result of contact with tobacco smoke, among these, losing its protective properties and becoming a factor damaging the oral cavity tissues [10].

One of the earliest local symptoms of nicotinism in the oral cavity is hygienic neglect. In addition, the composition 
of the microflora colonizing dental plague undergoes changes in favour of Gram-negative facultative anaerobic and obligate anaerobic rods that have been shown to have a strong destructive influence on the periodontal tissues $[5,6]$. Moreover, the oral cavity mucosa in people addicted to nicotine is atrophic, thickened, and shows a lower tendency to bleed than in non-smokers. This is an effect of nicotine and its metabolites on the organism. They disturb and change the circulation of peripheral blood, stimulate the release of adrenal and systemic catecholamines, cause the emergence of microthrombi and the closing of capillaries as a result of an increase in platelet adhesiveness and a decrease in the concentration of PGI2 (responsible for vessel dilatation and reduction of platelet aggregation). What is more, nicotine leads to ischaemia, through bringing about disorders in the maturation of erythrocyte precursors and erythrocytes [5].

Another effect of tobacco smoke is the activation of monocytes, which, in turn, leads to an increase in cytokine production. This results in the induction of fibroblasts, and, subsequently, to an increased production of proteases and other proteolytic enzymes that destroy connective tissue and stimulate the osteoclasts that are responsible for the destruction of the bone tissue of alveolar processes in the maxilla and mandible [5]. Apart from the afore-stated inflammatory and systemic disorders, the components of tobacco smoke may cause mutations in the p53 gene, leading to uncontrolled cell growth and neoplastic lesions $[4,10]$. Research has also shown that the tobacco smoke components disturb wound healing after tooth extraction or prosthetic implant placement, leading to inflammation in the surrounding tissues: bones and mucosa. In addition, they may cause atrophy of the bone surrounding the postoperative wound, resulting in failures in surgical and prosthetic treatment $[4,9]$.

A long-term addiction to nicotine leads to numerous inflammatory and neoplastic lesions and causes damage to the oral cavity tissues, while one of its most conspicuous consequences is the teeth loss that necessitates prosthetic treatment $[4,5,6]$.

\section{AIM}

The aim of the study was to determine the cigarette smoking-related profile of patients treated with implants, taking into account, as well, the patients' sex, age, and the correlation between smoking and the feeling of the pain accompanying treatment procedures.

\section{MATERIAL AND METHODS}

The study covered 464 patients, both women and men, aged between 20-74 years, treated with prosthetic implants at the Non-Public Health Centre "Dental" in Tomaszów Mazowiecki. The patients answered questions included in anonymous questionnaires which concerned sex, age, smoking period, number of cigarettes smoked per day, and pain sensation during bone reconstruction, implant placement and prosthetic procedures.

The surveyed patients were placed within groups according to sex - women $(n=228)$, men $(n=236)$; age - younger than 40 years $(n=157)$, between 40 and 60 years of age $(n=241)$ and older than 60 years $(n=66)$.

In the studied group of patients receiving implant prosthetic treatment, 156 respondents $(33.62 \%)$ declared that they were cigarette smokers, while 308 (66.38\%) respondents stated that they did not smoke.

The relationships between variables were analysed using the $\chi^{2}$ independence test. The statistical analysis was performed with Statistica 6.0 software (StatSoft Inc., Tulsa, Oklahoma, USA).

\section{RESULTS}

Our results reveal that non-smoking women were willing to undergo implant prosthetic treatment decidedly more often (73.68\% - almost 50\% more than those who smoked). Among men, non-smokers also opted for implant therapy more frequently $(59.32 \%)$, but the difference between smoking and non-smoking men was less than 20\%. Furthermore, non-smoking women and smoking men received implant prosthetic treatment significantly more often (Table 1). Of note, during treatment, the necessity to reconstruct the alveolar process bone before implantation was found in 115 patients.

Table 1. The studied patients according to sex and cigarette smoking habit

\begin{tabular}{|l|c|c|c|}
\hline \multirow{2}{*}{ Sex } & \multicolumn{2}{|c|}{ Cigarette smoking } & \multirow{2}{*}{ Total } \\
\cline { 2 - 4 } & Yes & No & \\
\hline \multirow{2}{*}{ Male } & 96 & 140 & 236 \\
\cline { 2 - 4 } & $40.68 \%$ & $59.32 \%$ & $100 \%$ \\
\hline \multirow{2}{*}{ Female } & 60 & 168 & 228 \\
\cline { 2 - 4 } & $26.32 \%$ & $73.68 \%$ & $100 \%$ \\
\hline \multirow{2}{*}{ Total } & 156 & 308 & 464 \\
\hline \multicolumn{2}{|c|}{ Test function value $x^{2}=10.145, \mathrm{p}=0.001$} \\
\hline
\end{tabular}

A statistically significant relationship was found between the respondents' sex and the number of years of tobacco smoking. Among women, 58.33\% of the respondents declared that they had been smoking cigarettes for over 20 years. In the male group, $73.96 \%$ of the patients receiving implant prosthetic treatment smoked for over 20 years. Women who smoked for no more than 20 years and men who smoked for over 20 years opted for implant therapy significantly more often (Table 2).

Table 2. The studied patients according to sex and cigarette smoking period

\begin{tabular}{|l|c|c|c|}
\hline \multirow{2}{*}{ Sex } & \multicolumn{2}{|c|}{ Cigarette smoking } & \multirow{2}{*}{ Total } \\
\cline { 2 - 4 } & $\begin{array}{c}\text { No more than } 20 \\
\text { years }\end{array}$ & Over 20 years & \\
\hline \multirow{2}{*}{ Male } & 25 & 71 & 96 \\
\cline { 2 - 4 } & $26.04 \%$ & $73.96 \%$ & $100 \%$ \\
\hline \multirow{2}{*}{ Female } & 25 & 35 & 60 \\
\cline { 2 - 4 } & $41.67 \%$ & $58.33 \%$ & $100 \%$ \\
\hline \multirow{2}{*}{ Total } & 50 & 106 & 156 \\
\hline \multicolumn{2}{|c|}{ Test function value $x^{2}=13.061, \mathrm{p}<0.001$} \\
\hline
\end{tabular}


Among men, half of the respondents (50\%) declared that they smoked no more than 20 cigarettes a day. In the group of women, $81.67 \%$ declared that they smoked no more than 20 cigarettes a day. Our results reveal that women who smoked no more than 20 cigarettes a day and men who smoked over 20 cigarettes a day opted for implant therapy significantly more often (Figure 1).

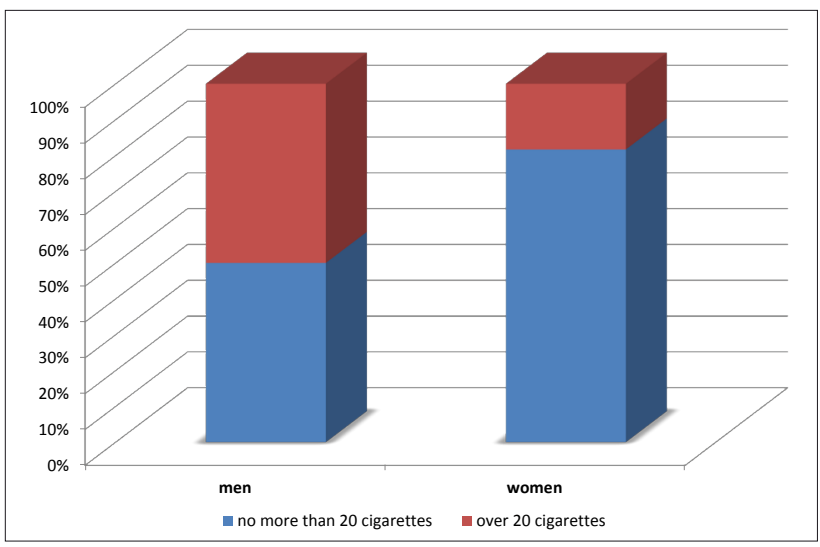

Figure 1. The studied men and women, according to the number of cigarettes smoked per day

In the group of smokers, the respondents aged 40-60 years opted for implant prosthetic treatment most frequently $(58.33 \%)$. In the non-smoking group, $48.70 \%$ of patients willing to receive implant therapy were 40-60 years old, while $39.94 \%$ were younger than 40 . Non-smokers aged less than 40 , as well as smokers aged 40-60 years and those older than $60(\mathrm{p}<0.001)$ opted for implant prosthetic treatment highly significantly more often (Table 3 ).

Table 3. Studied patients according to age and cigarette smoking practices

\begin{tabular}{|c|c|c|c|}
\hline \multirow{2}{*}{ Age (years) } & \multicolumn{2}{|c|}{ Cigarette smoking } & \multirow{2}{*}{ Tota } \\
\hline & Yes & No & \\
\hline \multirow{2}{*}{ Younger than 40} & 34 & 123 & \multirow{2}{*}{157} \\
\hline & $21.79 \%$ & $39.94 \%$ & \\
\hline \multirow{2}{*}{ Between 40 and 60} & 91 & 150 & \multirow{2}{*}{241} \\
\hline & $58.34 \%$ & $48.70 \%$ & \\
\hline \multirow{2}{*}{ Older than 60} & 31 & 35 & \multirow{2}{*}{66} \\
\hline & $19.87 \%$ & $11.36 \%$ & \\
\hline \multirow{2}{*}{ Total } & 156 & 308 & \multirow{2}{*}{464} \\
\hline & $100 \%$ & $100 \%$ & \\
\hline \multicolumn{4}{|c|}{ Test function value $x^{2}=16.263, p=0.0002$} \\
\hline
\end{tabular}

A smoking period shorter than 20 years was most frequently declared by respondents aged less than 40 years $(56.00 \%)$, while a smoking period longer than 20 years was declared by patients aged 40-60 years $(67.92 \%)$ and those over $60(26.42 \%)$. Patients who smoked for no more than 20 years and aged less than 40 , as well as those who smoked for over 20 years, aged $40-60$ years and over $60(p<0.001)$ opted for implant prosthetic treatment highly significantly more often (Table 4).
Table 4. The studied patients according to age and smoking period

\begin{tabular}{|c|c|c|c|}
\hline \multirow{2}{*}{ Age (years) } & \multicolumn{2}{|c|}{ Cigarette smoking } & \multirow{2}{*}{ Total } \\
\hline & $\begin{array}{c}\text { No more than } 20 \\
\text { years }\end{array}$ & Over 20 years & \\
\hline \multirow{2}{*}{ Younger than 40} & 28 & 6 & \multirow{2}{*}{34} \\
\hline & $56.00 \%$ & $5.66 \%$ & \\
\hline \multirow{2}{*}{ Between 40 and 60} & 19 & 72 & \multirow{2}{*}{91} \\
\hline & $38.00 \%$ & $67.92 \%$ & \\
\hline \multirow{2}{*}{ Older than 60} & 3 & 28 & \multirow{2}{*}{31} \\
\hline & $6.00 \%$ & $26.42 \%$ & \\
\hline \multirow{2}{*}{ Total } & 50 & 106 & \multirow{2}{*}{156} \\
\hline & $100 \%$ & $100 \%$ & \\
\hline
\end{tabular}

A statistically significant relationship was found between the age of patients receiving implant prosthetic treatment and the number of cigarettes smoked per day. In the group of patients younger than 40 years, $31.96 \%$ declared that they smoked no more than 20 cigarettes a day, while patients aged 40-60 years more frequently declared a smoking habit of over 20 cigarettes a day (62.71\%). Patients younger than 40 who smoked no more than 20 cigarettes a day, as well as those aged 40-60 years who smoked over 20 cigarettes a day opted for implant prosthetic treatment significantly more often $(\mathrm{p}<0.001)$ (Figure 2).

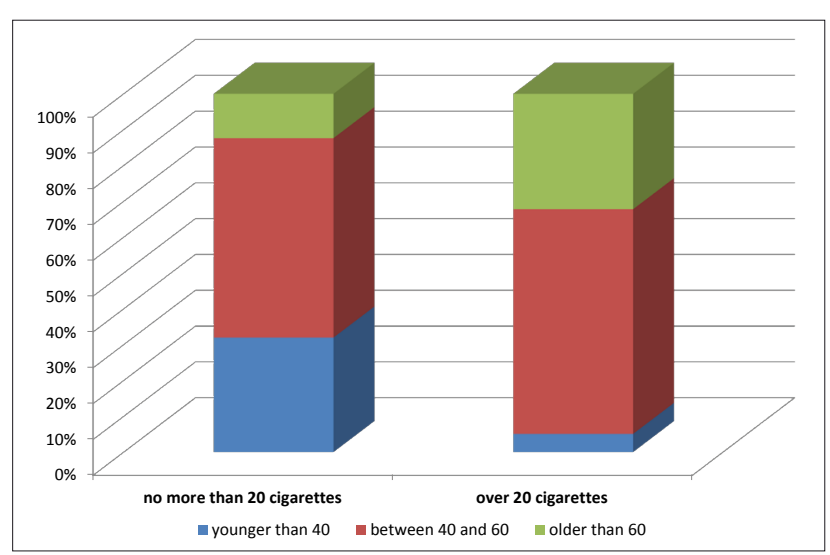

Figure 2. The studied patients, according to age and the number of cigarettes smoked per day

Our study noted that alveolar bone process reconstruction was performed in 115 patients, including 42 respondents who declared smoking, as well as 73 non-smokers. The results obtained from the questionnaire survey showed a statistically significant relationship between cigarette smoking and pain sensation during this bone reconstruction procedure. Among smokers, 71.43 declared no pain related to it. In the non-smoking group, over a half of the respondents $(50.68 \%)$ reported pain during the bone reconstruction procedure. Hence, pain sensation during the bone reconstruction procedure is significantly more often felt by non-smokers $(\mathrm{p}<0.05)$ (Figure 3$)$.

Among the studied patients who smoked tobacco, 76.92\% reported no pain during implant placement, while in the non-smoking group, $61.36 \%$ did not feel pain related to this procedure. Thus, non-smokers felt pain during implant placement significantly more often $(\mathrm{p}<0.05)$ (Table 5). 


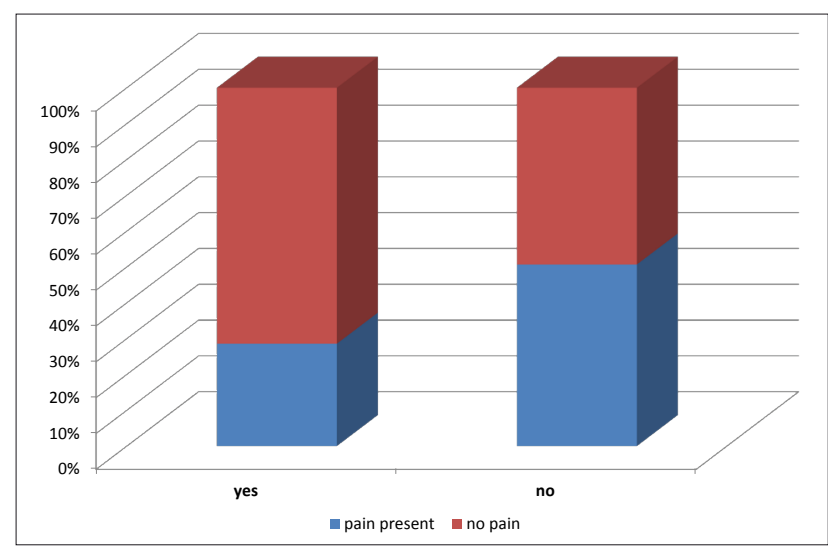

Figure 3. Pain felt by the patients during bone reconstruction vs. cigarette smoking

Table 5. Pain felt by the patients during implant placement, according to cigarette smoking habits

\begin{tabular}{|l|c|c|c|}
\hline \multirow{2}{*}{ Cigarette smoking } & \multicolumn{2}{|c|}{ Pain during implant placement } & \multirow{2}{*}{ Total } \\
\cline { 2 - 4 } & Present & Absent & \\
\hline \multirow{2}{*}{ Yes } & 36 & 120 & 156 \\
\cline { 2 - 4 } & $23.08 \%$ & $76.92 \%$ & $100 \%$ \\
\hline \multirow{2}{*}{ No } & 119 & 189 & 308 \\
\cline { 2 - 4 } & $38.64 \%$ & $61.36 \%$ & $100 \%$ \\
\hline Total & 155 & 309 & 464 \\
\hline \multicolumn{3}{|c|}{ Test function value $\mathrm{x}^{2}=11.269, \mathrm{p}=0.001$} \\
\hline
\end{tabular}

The relationship between patients feeling pain during prosthetic procedures and cigarette smoking was statistically significant. In the smoking group, $71.79 \%$ of the respondents did not feel pain during such action, while $58.12 \%$ of the non-smoking respondents did not feel pain during prosthetic procedures. Therefore, pain during prosthetic procedures was felt significantly more often by non-smokers $(p<0.005)$ (Table 6).

Table 6. Pain felt by the patients during prosthetic procedures, according to cigarette smoking practices

\begin{tabular}{|l|c|c|c|}
\hline \multirow{2}{*}{ Cigarette smoking } & \multicolumn{2}{|c|}{ Pain during prosthetic procedures } & \multirow{2}{*}{ Total } \\
\cline { 2 - 4 } & Present & Absent & \\
\hline \multirow{2}{*}{ Yes } & 44 & 112 & 156 \\
\hline \multirow{2}{*}{ No } & $28.21 \%$ & $71.79 \%$ & $100 \%$ \\
\hline \multirow{2}{*}{ Total } & 129 & 179 & 308 \\
\hline & $41.88 \%$ & $58.12 \%$ & $100 \%$ \\
\hline \multicolumn{2}{|c|}{173} & 291 & 464 \\
\hline
\end{tabular}

\section{DISCUSSION}

The results of an analysis of the extra-economic aspects of life-style practices in Poland show that every fourth Pole smokes cigarettes, and that the number of cigarettes he or she smokes is a little less than 15 a day. Of note, men and middle-aged persons with a vocational education, prevail among all smokers. In addition, male smokers constitute $32.7 \%$ of the general population, while the figure for female smokers is $18.8 \%$. Moreover, the highest percentage of smokers can be found in the age group 45-59 years $(34.0 \%)$
[2]. This means that within the group of patients who opt for implant prosthetic treatment, there are many persons suffering from nicotinism. In our study, the percentage of both smoking men and women treated with implants was, in either case, higher than in the cited study.

A review of the literature on implant prosthetic treatment failures related to tobacco smoking indicates that the research done to date, for the most part, shows a generally negative influence of tobacco smoking upon the prognosis in implant prosthetic treatment, in particular, in reference to periodontal tissues, oral cavity mucosa and implant-surrounding bone tissue. What is more, the authors stress that a rational consensus, from the vantage point of both the patient and the doctor, is to inform smoking patients about the risk of treatment failure which may be related to their addiction [8].

The studies undertaken reveal that the oral cavity of a cigarette smoker undergoes pathological changes affecting all the tissues. The mucosa and gum undergo atrophy and thicken. The bone tissue of alveolar processes of the maxilla and mandible is destroyed. Furthermore, a high activity of collagenase comes about within the tissues and the production of collagen is disturbed. What is more, the processes of tissue healing, epithelialization and the growth of new connective tissue are slowed down. Of particular note, the carbon monoxide contained in tobacco smoke leads to cell hypoxia, while hydrogen cyanide causes cell anoxia and tissue hypoxia. All the described destructive changes in tissues induce neurotransmission disorders. This leads to changes in taste and pain sensation in smokers $[3,4,5,7]$. The fact of changes in feeling pain seems to be confirmed by our study. It shows that a greater number of smoking patients, in comparison to non-smoking ones, felt no pain, both during the alveolar process bone reconstruction and implant placement, as well as during prosthetic procedures.

The previously cited study of the Polish population indicated that the percentage of people smoking cigarettes has decreased over the years [2]. This, however, does not change the fact that a numerous group of patients opting for implant therapy still suffer from nicotinism. It is, thus, important that dentists persuade patients to completely overcome their addiction. If this is impossible, they should inform patients about the necessity to refrain from smoking before the surgical procedure, as it has been found that some of the negative influence of smoking is eliminated if patients cease smoking even shortly before the surgical procedure is undertaken [1].

\section{CONCLUSIONS}

1. The most numerous group of patients treated with dental implants were non-smoking women or those who smoked for less than 20 years, and smoked no more than 20 cigarettes a day, as well as men aged 40-60 years and more who smoked for over 20 years, smoking more than 20 cigarettes a day.

2. Non-smoking patients felt pain during bone reconstruction, implant placement and prosthetic procedure more frequently. 


\section{REFERENCES}

1. Baljoon M., Natto S., Bergstrom J.: Long-term effect of smoking on vertical periodontal bone loss. J. Clin. Periodontol., 789, 32, 2005.

2. Czapiński J., Panek T., editors (2014). Diagnoza Społeczna 2013. Warunki i jakość życia Polaków. Raport. Warszawa: Centrum Rozwoju Zasobów Ludzkich; p. 265.

3. Milnerowicz H., Ściskalska M., Dul M.: Prozapalne oddziaływanie ksenobiotyków dymu tytoniowego. Med. Śr., 69, 17, 2014.

4. Pluta M., Nasiłowska-Barud A.: Uzależnienie od papierosów i jego toksyczne działanie na stan jamy ustnej. Zdr. Publ., 61, 122, 2012.

5. Rudziński R.: Wpływ metabolitów nikotyny na przebieg i intensywność zapaleń przyzębia przewlekłych u osób palących tytoń. Rocz. PAM., 97, 56, 2010.
6. Rudziński R., Banach J.: Wpływ dymu papierosowego na przebieg i stopień zaawansowania procesu zapalnego w tkankach przyzębia. Rocz. PAM., 88, 57, 2011.

7. Rudziński R. et al.: Nikotyna i jej główne metabolity a wybrane parametry periodontologiczne w ocenie narażenia na dym tytoniowy pacjentów z przewlekłym zapaleniem przyzębia. Dent. Med. Probl., 355, 48, 2011.

8. Szpak P., Szymańska J., Koszuta A.: Niepowodzenia w leczeniu implantoprotetycznym związane z paleniem tytoniu. Zdr. Publ., 310, 122, 2012.

9. Szyszkowski A., Kozakiewicz M.: Ocena wybranych czynników rokowniczych w leczeniu implantologicznym jamy ustnej. Mag. Stomatol., 12, 23, 2013.

10. Wnukiewicz J. et al.: Wpływ palenia papierosów na poziom inhibitorów cysteinowych peptydaz w ślinie. Czas. Stomatol.,108, 63,2010 . 